\title{
MicroRNAs and Long Noncoding RNAs as Novel Therapeutic Targets in Estrogen Receptor-Positive Breast and Ovarian Cancers
}

\author{
Tushar Singh Barwal ${ }^{1}$, Uttam Sharma ${ }^{1}{ }^{1}$, Sonali Bazala ${ }^{1}$, Ipsa Singh ${ }^{1}$, Manju Jain ${ }^{2}$, Hridayesh Prakash ${ }^{3}{ }^{(1)}$, \\ Shashank Shekhar ${ }^{4}$, Elise N. Sandberg ${ }^{5}$, Anupam Bishayee ${ }^{5, *(1)}$ and Aklank Jain ${ }^{1, *(1)}$
}

check for updates

Citation: Barwal, T.S.; Sharma, U.; Bazala, S.; Singh, I.; Jain, M.; Prakash, H.; Shekhar, S.; Sandberg, E.N.; Bishayee, A.; Jain, A. MicroRNAs and Long Noncoding RNAs as Novel Therapeutic Targets in Estrogen Receptor-Positive Breast and Ovarian Cancers. Int. J. Mol. Sci. 2021, 22, 4072. https://doi.org/10.3390/ ijms22084072

Academic Editor: Seok-Geun Lee

Received: 24 March 2021

Accepted: 12 April 2021

Published: 15 April 2021

Publisher's Note: MDPI stays neutral with regard to jurisdictional claims in published maps and institutional affiliations.

Copyright: (c) 2021 by the authors. Licensee MDPI, Basel, Switzerland. This article is an open access article distributed under the terms and conditions of the Creative Commons Attribution (CC BY) license (https:// creativecommons.org/licenses/by/ $4.0 /)$.
1 Department of Zoology, Central University of Punjab, Ghudda 151 401, Punjab, India; tushar101singhbarwal@gmail.com (T.S.B.); uttamsharma1994@gmail.com (U.S.); sonalibazala97@gmail.com (S.B.); ipsapoonam08@gmail.com (I.S.)

2 Department of Biochemistry, Central University of Punjab, Ghudda 151 401, Punjab, India; manjujainmda@gmail.com

3 Amity Institute of Virology and Immunology, Amity University, Noida 201 313, Uttar Pradesh, India; hridayesh.prakash@gmail.com

4 Department of Food Science and Technology, University of Agriculture Science, Bangalore 560 065, Karnataka, India; ssnk4343@gmail.com

5 Lake Erie College of Osteopathic Medicine, Bradenton, FL 34211, USA; elise.sandberg@gmail.com

* Correspondence: abishayee@lecom.edu or abishayee@gmail.com (A.B.); aklankjain@gmail.com (A.J.)

Abstract: Aromatase inhibitors (AIs) such as anastrozole, letrozole, and exemestane have shown to prevent metastasis and angiogenesis in estrogen receptor (ER)-positive breast and ovarian tumors. They function primarily by reducing estrogen production in ER-positive post-menopausal breast and ovarian cancer patients. Unfortunately, current AI-based therapies often have detrimental side-effects, along with acquired resistance, with increased cancer recurrence. Thus, there is an urgent need to identify novel AIs with fewer side effects and improved therapeutic efficacies. In this regard, we and others have recently suggested noncoding RNAs (ncRNAs), specifically microRNAs (miRNAs) and long noncoding RNAs (lncRNAs), as potential molecular targets for utilization in modulating cancer hallmarks and overcoming drug resistance in several cancers, including ERpositive breast and ovarian cancer. Herein, we describe the disruptive functions of several miRNAs and lncRNAs seen in dysregulated cancer metabolism, with a focus on the gene encoding for aromatase (CYP19A1 gene) and estrogen synthesis as a novel therapeutic approach for treating ERpositive breast and ovarian cancers. Furthermore, we discuss the oncogenic and tumor-suppressive roles of several miRNAs (oncogenic miRNAs: MIR125b, MIR155, MIR221/222, MIR128, MIR2052HG, and MIR224; tumor-suppressive miRNAs: Lethal-7f, MIR27B, MIR378, and MIR98) and an oncogenic lncRNA (MIR2052HG) in aromatase-dependent cancers via transcriptional regulation of the CYP19A1 gene. Additionally, we discuss the potential effects of dysregulated miRNAs and lncRNAs on the regulation of critical oncogenic molecules, such as signal transducer, and activator of transcription $3, \beta$-catenin, and integrins. The overall goal of this review is to stimulate further research in this area and to facilitate the development of ncRNA-based approaches for more efficacious treatments of ER-positive breast and ovarian cancer patients, with a slight emphasis on associated treatmentdelivery mechanisms.

Keywords: aromatase; CYP19A1 gene; aromatase inhibitor; lncRNA; miRNA; breast cancer; ovarian cancer; prevention; therapy

\section{Introduction}

While breast cancer is the fourth leading cause of cancer-related mortality in women, ovarian cancer is the most aggressive and fatal of all female reproductive cancers, with a five-year mortality rate of $\sim 80 \%$ when diagnosed in the 4 th stage [1]. With such powerful 
rates of prevalence and mortality in these respective cancer types, researchers have been on a strong pursuit to develop novel, biomarker-driven therapeutic agents against breast and ovarian cancer. In congruency with these efforts, the Food and Drug Administration (FDA) has approved several biomarker-based precision medicines, including Trastuzumab, which is indicated for breast cancer patients demonstrating human epidermal growth factor receptor 2 (HER2) gene amplification with subsequent elevations in protein level [2,3]. Unfortunately, despite recent advancements, highly specific molecular therapeutic strategies have still yet to reach maximum efficacy in clinical settings.

Current therapeutic strategies against breast and ovarian cancer involve blocking the estrogenic effects on tumors via endocrine therapy [4]. In this regard, conventional endocrine therapeutics entail treatment of estrogen receptor $\alpha(E R \alpha)$ in ER-positive female cancers. ER-modulating medications include tamoxifen and fulvestrant. Aromatase inhibitors (AIs), including letrozole, anastrozole, and exemestane, are also used as anticancer agents, for they suppress estrogen production in peripheral tissues by inhibiting the activity of the aromatase enzyme [5,6]. Aromatase (EC 1.14.14.1) is a critical enzyme that regulates the rate-limiting step involved in estrogen biogenesis, initiating the conversion of androgens to estrogens via three successive hydroxylation's and elimination of carbon at the 19th position of the androgens [7]. Aromatase is a product of the CYP19A1 gene, and it is an essential member of the cytochrome p450 superfamily, subfamily 19. CYP19A1 is a $123 \mathrm{~Kb}$ gene located on chromosome 15 at position q21.1, consisting of ten exonic and nine intronic regions, and it is found in all body tissues. Structurally, aromatase is a dimer of two complex polypeptides-one specific to cytochrome $\mathrm{P} 450$, a transcriptional product of the CYP19A1 gene, and the other to flavoprotein NADPH-cytochrome P450 reductase [8].

Overexpression of aromatase is associated with elevated systemic levels of estrogen, and is linked with the pathogenesis of hormone-associated disorders, including breast, ovarian, and endometrial cancer, as depicted in Figure 1 [9]. Recently, several studies have demonstrated the therapeutic potential of AIs used to treat estrogen-dependent cancers [10]. Unfortunately, the clinical uses of various AIs (e.g., letrozole, anastrozole, and exemestane) are limited due to detrimental side effects, such as deep vein thrombosis, cataract, loss of appetite, and osteoporosis, as well as the development of resistance to these drugs [11]. In this regard, noncoding RNAs (ncRNAs) have the potential to provide therapeutic and diagnostic alternatives for conventionally used AIs. Noncoding RNAs were once considered "junk DNA"; however, more recent studies have revealed that they perform a significant role in many critical biological functions associated with cancer, including cell proliferation, metastasis, and drug response [12]. Furthermore, ncRNAs (which include microRNAs [miRNAs] and long noncoding RNAs [lncRNAs]), have been implicated in regulating chromosome structure and DNA methylation patterns governing epigenetic regulation [13]. From a clinical perspective, ncRNAs hold promise as useful diagnostic/prognostic biomarkers due to their presence in several body fluids, including serum, saliva, and urine, suggesting that conventional invasive procedures such as tissue biopsy may not be required [14]. Additionally, they are highly specific, altered expression based on disease progression and clinicopathological characteristics [15].

In this review, we discuss the roles of ncRNAs, such as miRNAs and lncRNAS, in ER-positive breast and ovarian cancers and the potential applications of these molecules as novel targets for improved therapy. 


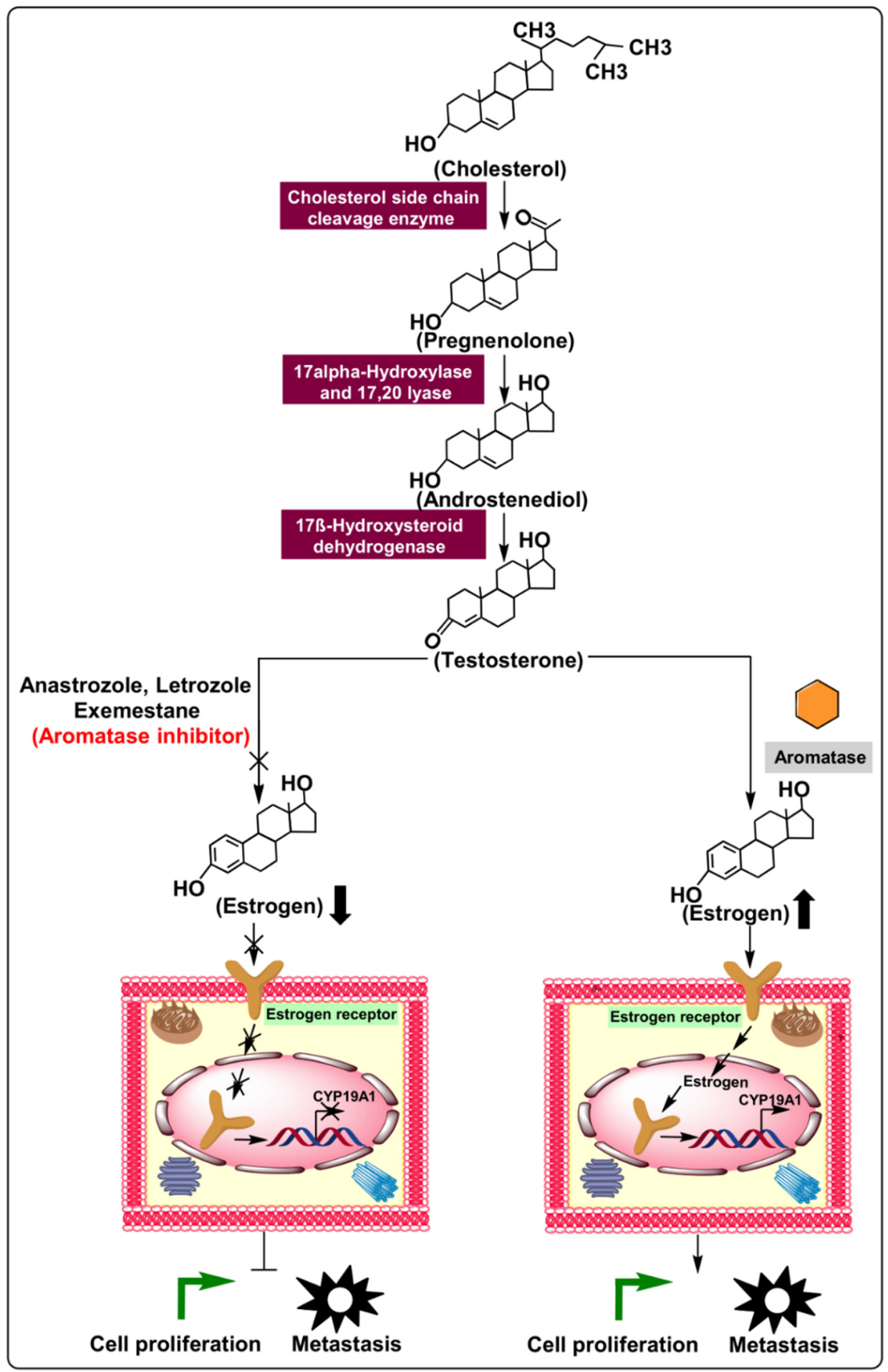

Figure 1. Biosynthesis of estrogen and mechanism of action of aromatase in cellular proliferation and metastasis via regulation of the estrogen production pathway. Additionally, aromatase inhibitors' relative preferences over typical ER-positive cancerous cells demonstrate enhanced cellular proliferation and metastasis.

\section{Methodology for Literature Search and Selection}

We utilized standard reporting items for systematic reviews and a meta-analysis (PRISMA) to analyze the literature for this review Figure 2 [16]. We considered the most up-to-date scientific research with no year restriction to provide a comprehensive set of information to readers. We performed a literature search employing multiple online 
databases dated 1/Jan/2021, such as PubMed (470), ScienceDirect (120), Willey (70), Google Scholar (630), and Lexis Nexis (523). Primary screening led to the identification of 343 studies after duplicate removal. These studies were selected based on the title, keywords, and abstract content, which were used to screen for eligibility of relevant results. After further review, we were able to narrow down 35 relevant studies. This step was followed by qualitative evaluation involving full-text analysis, exclusion of data which were incomplete, and highly qualitative data or bioinformatic studies employing data from The Cancer Genome Atlas database, producing 14 results. For post-qualitative screening, we eliminated reviews, meta-analysis, meeting reports, patents, book chapters, and conference abstracts, yielding 10 relevant articles for final analysis. The literature search was performed by an individual author (TSB) in consultation with a senior author (AJ) of this review.

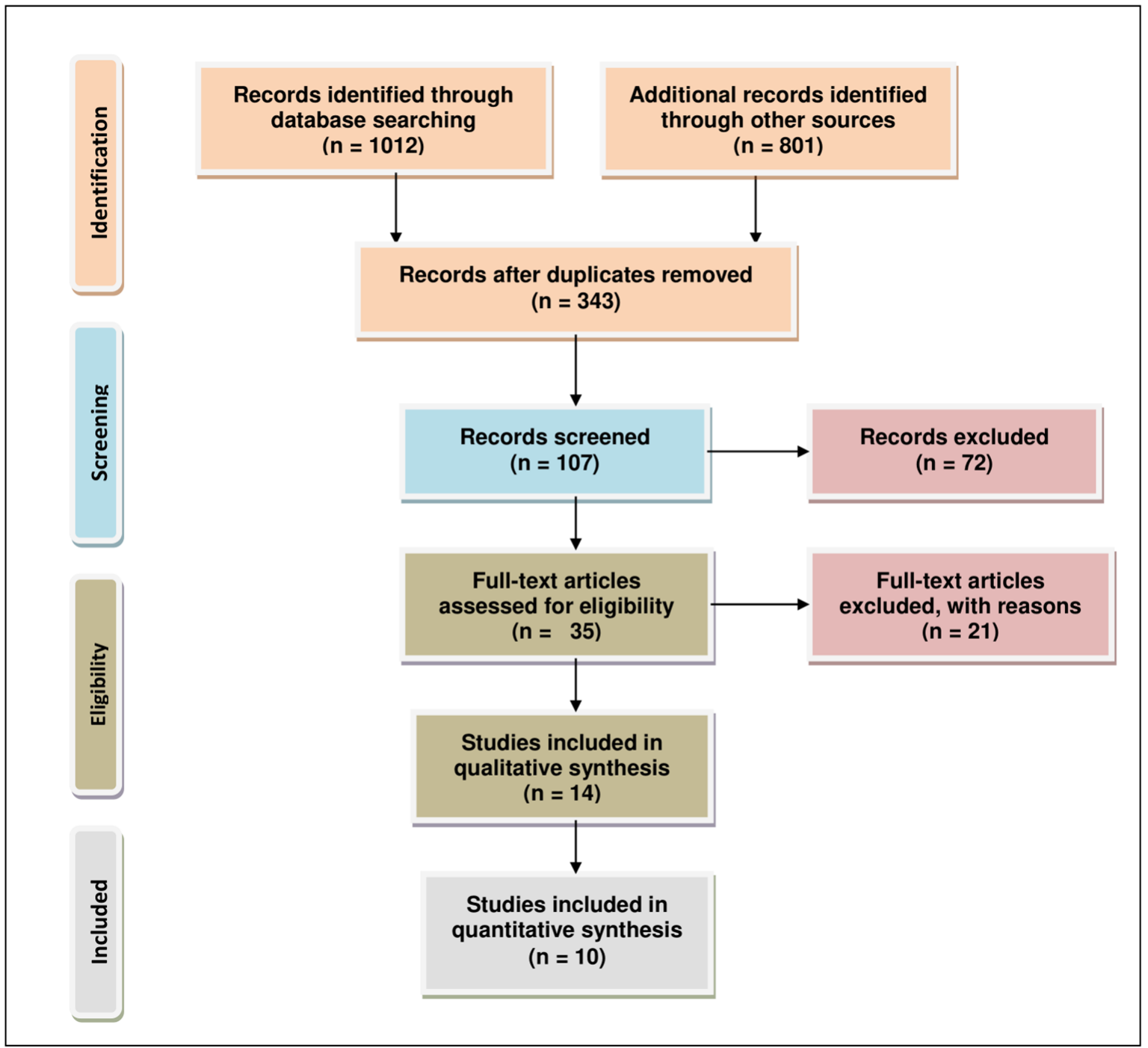

Figure 2. PRISMA flow chart describing the process of literature search and study selection related miRNA, lncRNA, aromatase inhibitor, and ER-positive breast and ovarian cancers. The total number of 10 relevant articles are included in this review.

\section{Noncoding RNAs (miRNAs and lncRNA) and Their Aberrant Expression in ER-Positive Breast Cancer}

Despite recent advances in cancer therapeutic and diagnostic methodologies, breast cancer remains a significant clinical, scientific, and societal challenge [17], representing the second leading cause of cancer-related mortalities globally [18]. Recent studies have shown that $\sim 70 \%$ of breast cancers can be classified as estrogen receptor alpha-positive, belonging 
to the molecular subtype luminal A or luminal B [16]. Though the mechanisms involved in breast cancer etiology are not fully understood, the present scientific data demonstrate a robust correlation between estrogen levels and the development and progression of the disease [19]. The proliferative and metastatic potential of ER-positive breast cancer cells are often governed by the estrogen signalling pathway; hence, estrogen-blocking strategies for hormone-sensitive tumors have been effective in reducing tumor growth. Aromatase is an example of a target for estrogen-blocking therapeutics, as it is an enzyme involved in regulating estrogen production in visceral fat cells. Recently, miRNAs and lncRNA have been identified as potential target molecules that can downregulate levels of aromatase at the mRNA level [20-22]. Contrary to the conventional notion, recent work has found them to serve as important functional, regulatory molecules [23]. Therefore, a more thorough understanding of the complex ncRNA (miRNAs and lncRNA)-related networks and interactions in cells might provide a unique opportunity for the development of improved molecular suppressors against aromatase as alternatives to conventionally used AIs. In the following section, we discuss several ncRNAs that have been found to have regulatory potential in breast cancer progression.

\subsection{Aromatase Associated with miRNAs Aberrantly Expressed in Breast Cancer 3.1.1. Lethal-7f}

Lethal-7f is a miRNA located on chromosome 9 at position $9 \mathrm{q} 22.32$ that can modulate developmental timing and cellular differentiation [24,25], and its dysregulated expression has been associated with cancer initiation and progression [26]. Lethal-7f has 13 family members, encoding 9 mature miRNAs (let-7a, let-7b, let-7c, let-7d, let-7e, let-7f, let-7g, let-7i, and $m i R-98)$, which have overlapping functions due to high sequence similarity [27].

Mechanistically, lethal-7f downregulates $\beta 2$-adrenergic receptor ( $\beta 2$-AR) levels by interacting with the $3^{\prime}$-UTR (untranslated region) of the gene coding $\beta 2$-AR levels in human epidermal growth factor receptor 2 (HER2)-positive breast cancer patients, as demonstrated in MCF-7, SKBR3 and BT474 cell lines. $\beta 2$-adrenergic receptor disruption leads to suppression of downstream molecules, such as matrix metalloproteases (MMPs) and vascular endothelial growth factor (VEGF), which reduces tumor invasion and angiogenesis [28]. Shibahara et al. (2012) have demonstrated a negative correlation between lethal-7f and CYP19A1 mRNA levels in breast cancer tissues $(\mathrm{n}=3)$, further validated using human breast cancer cell lines, MCF-7 and SK-BR-3 (Table 1). Lethal-7f has also been shown to contribute to estrogen depletion and decreased tumor cell proliferation via sponging of the CYP19A1 gene (2.44-fold decrease) interacting with 3'-UTR, as depicted in Figure 3 [29]. Further studies on lethal-7f are still required with a large number of patients.

Furthermore, lethal-7f has been shown to modulate tumor cells' sensitivity to chemotherapy and radiation in various human malignancies [30]. Therefore, lethal-7f represents a potential therapeutic molecule against breast cancer.

\subsubsection{MIR125B1}

MIR125B1 is a miRNA located on chromosome 21 at position 21q221.31 that can modulate several cellular processes [31]. Based on its cellular context, it acts as a tumor proliferator, or oncogene, in breast cancer [32], ovarian cancer [33], gliomas [33]. Furthermore, several studies have demonstrated the proliferative potential of MIR125B1in breast cancer via its targeting of the tumor suppressor $p 53$ gene, which upregulates proliferative tumor pathways like PI3K (Phosphatidylinositol 3-kinase) pathways. Subsequently, this promotes upregulation of several oncogenic pathways, including the Akt/mTOR axis. Akt is a protein kinase B that, when stimulated, upregulates mechanistic target of rapamycin (mTOR), which contributes to many growth processes of cells and further contributes to tumor proliferation [34,35]. Vilquin et al. (2015) have demonstrated the proliferative potential of MIR125B1 via its ability to upregulate aromatase levels in breast cancer tissues $(\mathrm{n}=65)$ compared to an equivalent number of healthy controls. Mechanistically, MIR125B1 upregulated the Akt/mTOR pathway and reduced the therapeutic potential of letrozole 
in breast cancer patients, as depicted in Figure 3 [34]. Furthermore, the proliferative role of MIR125B1in ER-positive breast cancer was validated by Vilquin et al. (2015), who employed MCF-7 cell line subjected to an increasing concentration $(1,3$ and $5 \mu \mathrm{m})$ of letrozole drug [34]. Based on these scientific findings, we might conclude that MIR125B1 blockers represent a potential therapeutic target against ER-positive breast cancer (Table 1). In further support of this idea, suppression of MIR125B1 has demonstrated the ability to not only reduce letrozole resistance but to suppress several other oncogenic molecules affecting tumor proliferation. Furthermore, upregulated levels of MIR125B1 can serve as a prospective diagnostic biomarker for ER-positive breast cancer, as depicted in Figure 3.
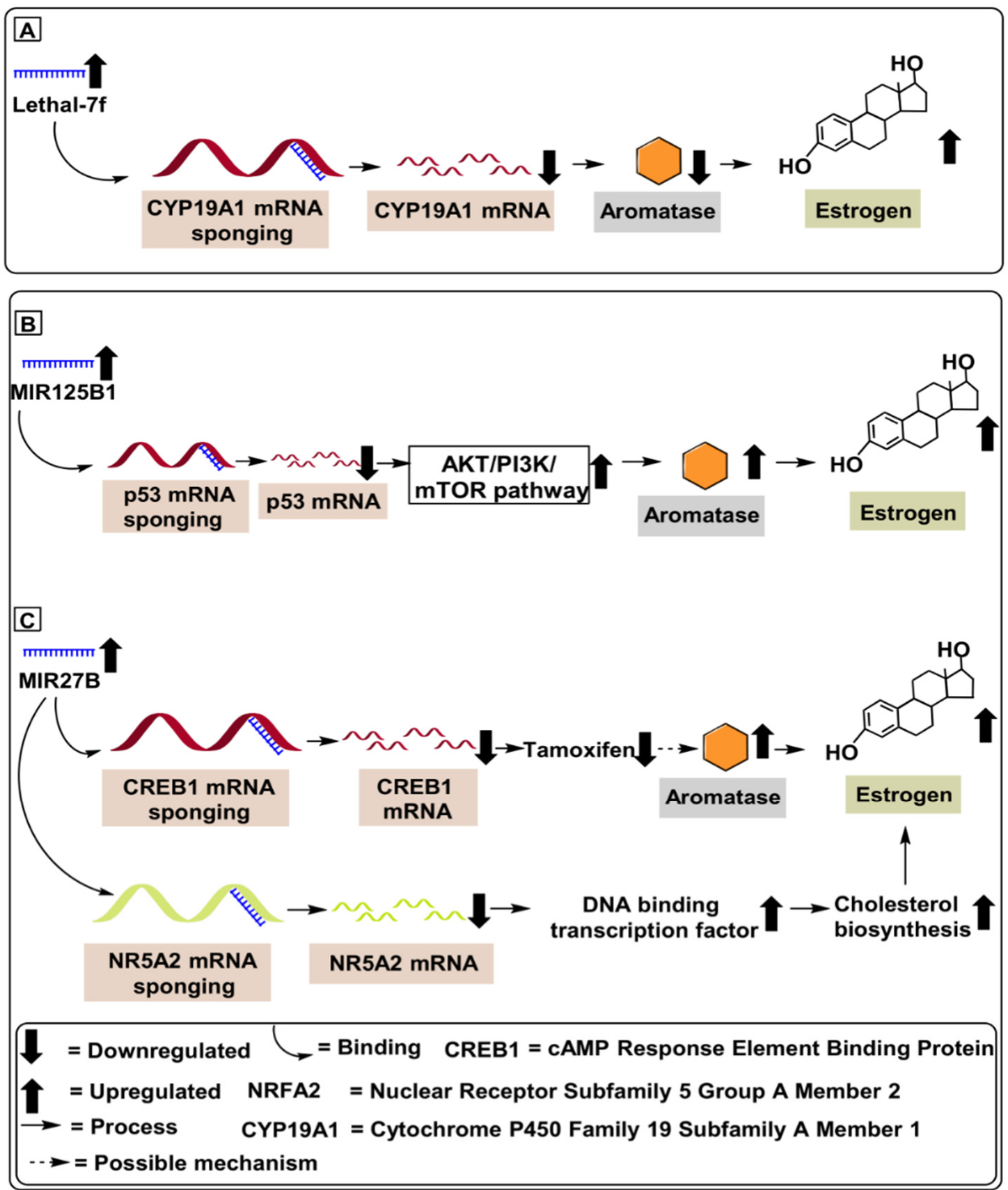

Figure 3. MicroRNAs involved in aromatase regulation in breast cancer. (A) Role of Lethal-7f downregulating CYP19A1 mRNA levels in breast cancer patients. (B) Role of MIR125B1 in upregulating aromatase level by activating Akt/PI3K/mTOR pathway, contributing to chemoresistance and increasing tumor proliferation. (C) Role of MIR27B in downregulating CREB1 and NR5A2 mRNA, upregulating aromatase level and cholesterol biosynthesis in breast cancer patients. 
Table 1. Dysregulated ncRNAs associated with aromatase dysregulation in breast cancer.

\begin{tabular}{|c|c|c|c|c|c|c|}
\hline S. No. & $\begin{array}{l}\text { Dysregulated } \\
\text { miRNA/lncRNA }\end{array}$ & $\begin{array}{l}\text { Chromosomal } \\
\text { Location }\end{array}$ & Patient Sample & Cell Lines Used & Animal Model Used & References \\
\hline \multicolumn{7}{|c|}{ Tumor-suppressive } \\
\hline 1 & Lethal-7f & $9 q 22.32$ & $\begin{array}{l}3 \text { Frozen human breast } \\
\text { cancer tissues }\end{array}$ & MCF-7 \& SK-BR-3 & N.A. & {$[24,25,29]$} \\
\hline \multicolumn{7}{|c|}{ Oncogenic } \\
\hline 2 & MIR125B1 & $21 q 221.31$ & $\begin{array}{l}65 \text { Human breast cancer } \\
\text { tissues and equivalent } \\
\text { number of control samples }\end{array}$ & $\begin{array}{c}\text { MCF-7 } \\
\text { (Dosing: } 1,3 \text { and } \\
5 \mu \mathrm{m} \text { letrozole) }\end{array}$ & N.A. & {$[31,34]$} \\
\hline 3 & MIR27B & $9 q 22.32$ & $\begin{array}{l}53 \text { Human breast cancer } \\
\text { tissues and } 19 \text { healthy } \\
\text { tissues }\end{array}$ & MCF-7 \& TAM-1 & N.A. & {$[36-38]$} \\
\hline 4 & MIR155 & $21 \mathrm{q} 21.3$ & N.A. & MCF-7 \& ZR75-1 & $\begin{array}{c}\text { Ncr foxhed nude mice } 6 \text { to } \\
8 \text { weeks old given a } \\
1 \mathrm{mg} / \mathrm{kg} \text { of letrozole for } \\
21 \text { days }\end{array}$ & {$[39,40]$} \\
\hline 5 & MIR221/222 & Xp11.3 & N.A. & $\begin{array}{l}\text { MCF-7 (Dosing: } \\
100 \mathrm{nM} \\
\text { fulvestrant) }\end{array}$ & N.A. & {$[41,42]$} \\
\hline 6 & MIR128-1 & $2 q 21.3$ & N.A. & MCF-7 & N.A. & {$[43,44]$} \\
\hline 7 & MIR2052HG & $8 \mathrm{q} 21.11$ & $\begin{array}{l}5221 \text { Breast cancer blood } \\
\text { sample }\end{array}$ & N.A. & N.A. & [45-47] \\
\hline
\end{tabular}

N.A., not available.

\subsubsection{MIR27B}

MIR27B is a miRNA located on chromosome 9 at position 9q22.32 that modulates tumor suppression in breast cancer [36,37]. MIR27B is a well-validated tumor suppressor and mechanistically modulates critical oncogenic molecules such as the nuclear receptor subfamily 5 group A member 2 gene (NR5A2) and response element-binding protein (CREB1). MIR27B mRNA binds to the $3^{\prime}-\mathrm{UTR}$ of the NER5A2 gene, a critical proteincoding gene involved in the expression of essential genes, such as DNA binding zinc finger transcription factor and cholesterol biosynthesis, which promote suppression of cancer proliferation. Similarly, MIR27B mRNA binds with the 3'-UTR of the CREB1 gene, which blocks estrogen-induced transcription due to lack of inducer transcripts for DNA binding protein suppressing tumor proliferation [38].

Demonstrating the regulatory potential of MIR27B in overcoming tamoxifen-resistant ER-positive breast cancer, Zhu et al. (2016) illustrated the reduced tamoxifen-resistance potential of MIR27B mRNA inhibiting NR5A2 and CREB1 genes in MCF-7 and TAM-1 (tamoxifen-resistant) cell lines. Furthermore, Zhu et al. (2016) validated the reduced tamoxifen-resistance in breast cancer from 53 tumor samples, compared with 19 healthy tissue samples (Table 1) [38]. Based on these scientific findings, we might conclude that MIR27B represents a potential therapeutic target against ER-positive breast cancer. Suppression of MIR27B not only reduces tamoxifen resistance; it also suppresses several other oncogenic molecules affecting tumor proliferation, as depicted in Figure 3.

\subsubsection{MIR155}

MIR155 is a miRNA located on chromosome 21 at position 21q21.3 that modulates several oncogenic pathways in breast cancer patients [39]. It is a well-validated tumor proliferator that is highly overexpressed in several solid tumors, such as thyroid carcinoma [48], breast cancer [41,49,50], colon cancer [41], cervical cancer [51], pancreatic ductal adenocarcinoma (PDAC) [52], and lung cancer, and the aberrant expression of MIR155 is associated with poor prognosis [53]. Mechanistically, MIR155 suppresses MIR143, a welldocumented tumor suppressor [54], via targeting the activation of STAT3 gene targeting c/EBPB (a transcriptional activator for MIR143) [40]. 
Demonstrating the regulatory potential of MIR155 in overcoming letrozole-resistance in ER-positive breast cancer, Bacci et al. (2016) conducted in-vivo experiments using MCF-7 and ZR75-1 (letrozole-resistant) breast cancer cell lines. Additionally, Bacci et al. (2016) validated the in vitro experiments by performing in vivo experiments using female Ncr foxhed nude mice 6 to 8 weeks old, who were given $1 \mathrm{mg} / \mathrm{kg}$ of letrozole for 21 days (Table 1). Furthermore, the authors further demonstrate an upregulated expression of MIR155 in letrozole-resistance in ER-positive breast cancer cells. Mechanistically, MIR155 upregulates SLC16A3 gene encoding monocarboxylate transporter 4 protein (MCT4) and glucose transporter 1 (GLUT-1) gene, increasing letrozole resistance in ER-positive breast cancer [40]. Therefore, using a suitable MIR155 miRNA blocker molecule might act as a potential therapeutic molecule against letrozole resistance in ER-positive breast cancer. Furthermore, upregulated levels of MIR155 can serve as a prospective diagnostic biomarker against ER-positive breast cancer, as depicted in Figure 4.

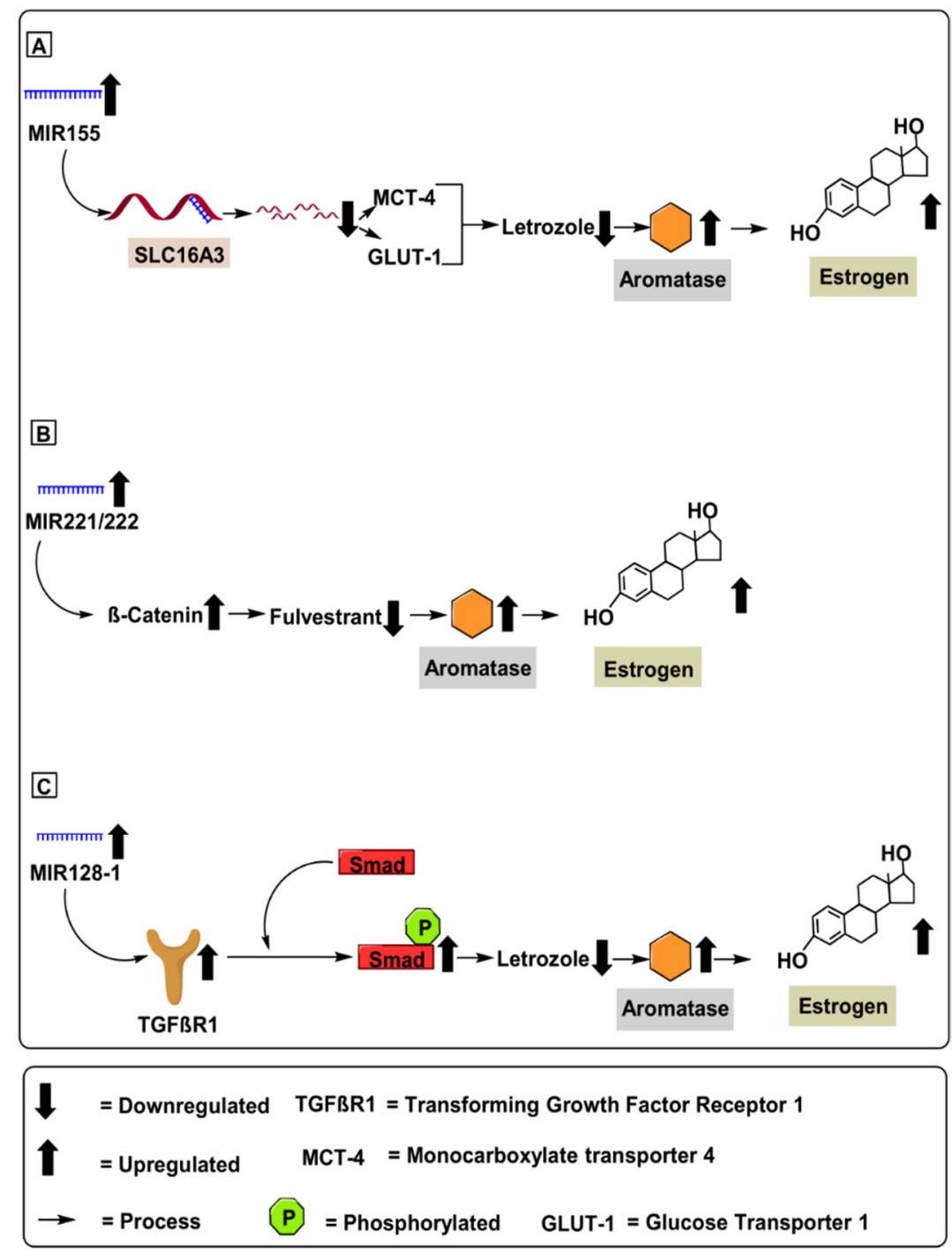

Figure 4. MicroRNAs involved in aromatase regulation in breast cancer. (A) Role of MIR155 upregulating aromatase levels via mRNA degradation of SLC16A3 gene encoding monocarboxylate transporter 4 protein (MCT4) and glucose transporter 1 (GLUT-1) gene increasing letrozole resistance in ER-positive breast cancer. (B) Role of MIR221/222 in upregulating aromatase level by activating $\beta$-catenin pathway contributing to increased fluvestrate resistance in breast cancer cells. (C) Role of MIR128-1 in upregulating aromatase level by activating transforming growth factor receptor-1 (TGF $\beta-R 1)$ pathway, which initiates cell growth, apoptosis, differentiation and fibrosis. 


\subsubsection{MIR221 and MIR222}

MIR221 and MIR222 are two highly homologous microRNAs located on chromo-

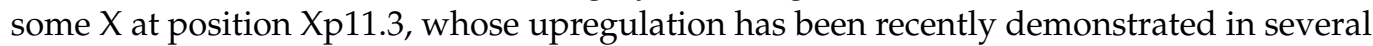
types of human tumors [41]. Overexpression of MIR221 \& MIR222 is associated with several advanced malignancies via suppression of critical cell cycle regulators, such as p27Kip1 [55]. The inverse correlation amongst p27Kip1 with MIR221 \& MIR222 was confirmed in glioblastomas, thyroid papillary carcinomas, breast cancer, hepatocellular carcinoma, and lung cancer [56]. Mechanically, MIR221 \& MIR222 upregulation in breast cancer was correlated with downregulated $p 53$ gene profile, leading to an upregulated expression of critical oncogenic pathways such as the PI3K (Phosphatidylinositol 3-kinase) pathways, and subsequent upregulation of several oncogenic pathways such as the Akt (protein kinase B) and mTOR pathway, further contributing to tumor proliferation [34]. Demonstrating the regulatory potential of MIR221 \& MIR222 in overcoming fulvestrant resistance in ER-positive breast cancer, Rao et al. (2011) conducted in vivo experiments using MCF-7 (fulvestrant-resistant) breast cancer cell lines dosed with $100 \mathrm{nM}$ of fulvestrant (Table 1). Mechanistically, MIR221 \& MIR222 upregulated $\beta$-catenin mRNA levels, contributing to increased fulvestrant resistance in MCF-7 breast cancer cell lines [57]. Furthermore, $\beta$-catenin is a critical oncogenic molecule associated with crucial roles; for instance, promoting cell-cell adhesion [58], upregulating cell proliferation, mediating EMT, and enhancing cell resistance to chemoradiotherapy in breast cancer [42]. Therefore, using a suitable MIR-221 \& MIR-222 blocker molecule might act as a potential therapeutic agent against fulvestrant resistance in ER-positive breast cancer. Furthermore, upregulated MIR$221 \& M I R-222$ can serve as a prospective diagnostic biomarker against ER-positive breast cancer, as depicted in Figure 4.

\subsubsection{MIR128-1}

MIR128-1 is an endogenous miRNA that is 18-24 nucleotides long and located on chromosome 2 at position 2q21.3. It has been shown to modulate tumorigenesis and metastasis in several cancers. Subsequently, MIR128-1 is considered a key biomarker for the diagnosis and prognosis of cancers, as well as an effective agent for targeted therapy of malignant tumors. Furthermore, MIR128-1 targets several oncogenes governing tumor proliferation, differentiation, apoptosis, invasion, and metastasis, providing essential cues for the development of novel therapeutic strategies for cancer prevention and treatment [43]. Mechanistically, MIR128-1 downregulates ARPP21 (CAMP-regulated phosphoprotein 21) gene, a crucial gene that inhibits apoptosis and confers increased chemo-radiotherapy resistance in breast cancer cells [59].

Demonstrating the regulatory potential of MIR128-1 in overcoming letrozole resistance in ER-positive breast cancer, Masri et al. (2012) conducted an in vivo experiment using MCF-7 breast cancer cell lines overexpressing the aromatase gene (Table 1). Mechanistically, MIR128-1 upregulates the transforming growth factor- $\beta$ receptor 1 (TGF $\beta R 1$ ) gene associated with re-sensitization of letrozole resistance in ER-positive breast cancer [44]. Furthermore, TGF $\beta$ R1 recruits and phosphorylates receptor-regulated Smads (R-Smads) when phosphorylated. Additionally, the TGF $\beta R 1$ gene regulates cell growth, apoptosis, differentiation, and fibrosis [60]. Therefore, using a suitable MIR128-1 blocker molecule might act as a potential therapeutic molecule against fulvestrant resistance in ER-positive breast cancer. Furthermore, upregulated MIR128-1 can serve as a prospective diagnostic biomarker against ER-positive breast cancer, as depicted in Figure 4.

\subsection{Aromatase Associated with miRNAs Aberrantly Expressed in Breast Cancer}

Long noncoding RNAs (lncRNAs) are a subtype of ncRNAs that are $>200$ nucleotides in length $[13,14,61-63]$, and several have been implicated in the development and progression of breast cancer [31]. LncRNAs can act as promoters or suppressors during breast cancer progression via molecular mechanisms that include modulating cellular proliferation, invasion, apoptosis, and drug resistance [12,14]. Unlike miRNAs, knowledge of the 
functional roles of lncRNAs is still somewhat limited [64]. In the subsequent section, we discuss the potential of several lncRNAs in regulating estrogen levels via the regulation of the aromatase enzyme.

\section{MIR2052HG}

MIR2052HG is a lncRNA that is $32.4 \mathrm{~kb}$ in length and located on chromosome 18 at position 8q21.11. MIR2052HG has been associated with breast cancer [45,46]; however, the mechanism(s) involved are not yet fully defined. A correlation has been identified between MIR2052HG and aromatase levels in MCF7 and CAMA-1 (ER $\alpha$-overexpressing breast adenocarcinoma) cell lines. Further, MIR2052HG was found to regulate ER $\alpha$ expression through transcriptional regulation of the estrogen receptor 1 (ESR1) and ER protein degradation, as schematically outlined in Figure 5. MIR2052HG has been found to regulate Lemur tyrosine kinase 3 (LMTK3) transcription, in which the transcribed MIR2052HG and LMTK3 gene transcripts interact with the early growth response 1 (EGR1) protein to initiate movement of the complex toward the LMTK3 locus. This results in the upregulation of aromatase, mitogen-activated protein kinase (MAPK), and protein kinase $\mathrm{B} /$ forkhead box O3 (Akt/FOXO3), leading to ER $\alpha$ and ESR1 stability, as depicted in Figure 5. The introduction of MIR2052HG lncRNA blockers in MCF7 and CAMA-1 cell lines led to a significant decrease in ER $\alpha$ [47]. Similarly, Ingle et al. (2017) demonstrated that depletion of MIR2052HG via siRNA resulted in decreased expression of ER $\alpha$, both at the mRNA and the protein levels, in MCF7 and AC1 human gestational choriocarcinoma cell line [20]. Consistent with these results, Ingle et al. (2017) also found increased levels of MIR2052HG in 253 breast cancer patients, compared to 4406 healthy controls [21].

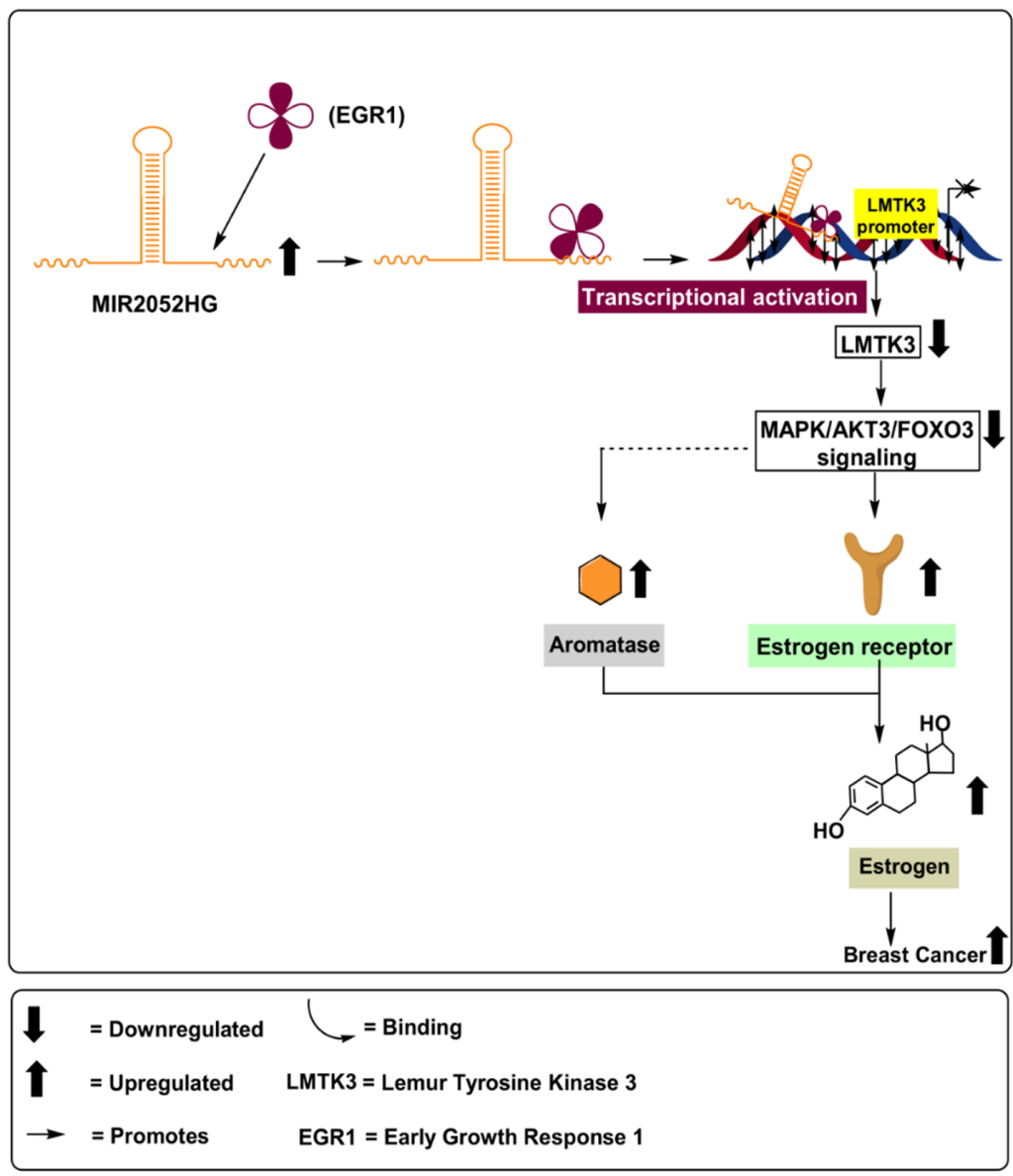

Figure 5. Role of lncRNA MIR2052HG in upregulating aromatase levels via activation of MAPK/Akt3/FOXo3 signalling pathways, leading to increased ER $\alpha$ and ESR1 stability in breast cancer patients. 
MIR2052HG was found to regulate Akt-dependent FOXO3 expression. Its depletion led to overexpression of FOXO3 in MCF7 / AC1 cells, resulting in a significant decrease in ER $\alpha$ mRNA and protein levels (Table 1). Therefore, based on the results discussed above, the depletion of MIR2052HG may be associated with reduced aromatase levels, decreased estrogen levels, and reduced cellular proliferation and tumor metastasis [21]. However, further studies are warranted to better understand the involved mechanisms and pathways modulated by MIR2052HG.

\section{MiRNAs and Their Aberrant Expression in ER-Positive Ovarian Cancer}

Universally acknowledged as a "silent killer," ovarian cancer is often not diagnosed until it has progressed to advanced stages. This is in part due to a delayed onset of symptoms and lack of efficient screening $[65,66]$. In support of this, statistics have shown that $>70 \%$ of ovarian cancer cases are not diagnosed until the tumor has progressed to an advanced stage, in which the average five-year survival rate is only 50\% [67]. Epidemiological data suggests that ovarian cancer induction and proliferation are impacted by lifetime estrogen exposure [68]. Experiments have revealed that ovarian cancer shares estrogen-regulated pathways with breast, cervical, and endometrial cancers [69], as the estrogens stimulate tumor growth by binding to and activating the ER. Several largescale studies have displayed that $\sim 36 \%$ of ovarian cancers are ER-positive [70]. Therefore, estrogen-blocking strategies have high applicability in regulating estrogen production in the visceral fat cells [71].

According to the National Comprehensive Cancer Network (NCCN) guidelines, hormonal therapies including anastrozole (aromatase inhibitor), letrozole (aromatase inhibitor), leuprorelin acetate (gonadotropin-releasing hormone analog), megestrol acetate (synthetic progestin), and tamoxifen (anti-estrogen) are all classified as approved treatments for recurrent forms of epithelial ovarian cancers [72]. Therefore, the development of additional hormone-based therapies may be beneficial for these patients. In this regard, miRNA provides a lower dose inhibitory analogy, providing easier manipulation due to absolute expression levels and avoiding oligonucleotide-associated toxicity [73]. In the following section, we discuss the roles of several miRNAs that have been implicated in ovarian cancer progression.

\subsection{MIR224}

MIR224 is located on chromosome $\mathrm{X}$ at position Xq28. MIR224 performs critical generegulating functions involved in chemoresistance in A2780CP/A2780S and C13/OV2008 ovarian cancer cells, via regulating the PRKCD (protein kinase $C$ delta) pathway. Additionally, the oncogenic potential of MIR224 was validated using 41 ovarian papillary serous carcinomas (OPSC) [74]. Hu et al. (2016) demonstrated the proliferative potential of MIR224 via targeting the KLLN pathway in HO8910 (low metastatic ability) and HO8910PM (high metastatic ability) ovarian cancer cell lines. Hu et al. (2016) further illustrated KLLN protein's (Killin, P53 Regulated DNA Replication Inhibitor) suppression via MIR224, which fostered a downstream target, cyclin A, to initiate proliferation in epithelial ovarian cancer cells [74]. Yao et al. (2010) demonstrated a strong correlation amongst upregulated expression levels of CYP19A1 mRNA (5-fold upregulation) and MiR-224 in KGN cell lines. Mechanistically, MIR224 enhanced TGF- $\beta 1$ protein levels, which induced GC proliferation by targeting Smad4 protein and led to a subsequent increase in the CYP19A1 mRNA levels. Furthermore, Yao et al. (2010) validated the proliferative potential of MIR224 by employing adult ICR female mice Table 2 [74]. Similarly, Lite et al. (2019) illustrated the aromatase-enhancing potential of MIR224 using three-months-old nulliparous rats [75].

Based on these results, we propose that MIR224 represents a potential biomarker for ovarian cancer (Figure 6). However, further studies are warranted, particularly those designed to delineate the underlying molecular mechanisms involved in MIR224-associated ovarian cancers. Unfortunately, additional human studies are warranted to mandate the diagnostic potential of MIR-378. 
Table 2. Dysregulated miRNAs associated with aromatase dysregulation in ovarian cancer.

\begin{tabular}{|c|c|c|c|c|c|c|}
\hline S. No. & $\begin{array}{l}\text { Dysregulated } \\
\text { miRNA/lncRNA }\end{array}$ & $\begin{array}{l}\text { Chromosomal } \\
\text { Location }\end{array}$ & Patient Samples & $\begin{array}{l}\text { Cell Lines } \\
\text { Used }\end{array}$ & $\begin{array}{c}\text { Animal Model } \\
\text { Used }\end{array}$ & References \\
\hline \multicolumn{7}{|c|}{ Oncogenic } \\
\hline 1 & MIR224 & $\mathrm{Xq} 28$ & N.A. & KGN cell lines & $\begin{array}{l}\text { Three-months-old } \\
\text { nulliparous rats }\end{array}$ & {$[74,75]$} \\
\hline \multicolumn{7}{|c|}{ Tumor Suppressive } \\
\hline 2 & MIR378 & $5 q 32$ & N.A. & KGN cell lines & Porcine ovaries & {$[76,77]$} \\
\hline 3 & MIR98 & Xp11.22 & $\begin{array}{l}\text { Tissues from } 52 \text { ovarian } \\
\text { cancer patients and } 15 \\
\text { healthy control samples }\end{array}$ & Ishikawa cells & N.A. & {$[78,79]$} \\
\hline
\end{tabular}

N.A., not available.
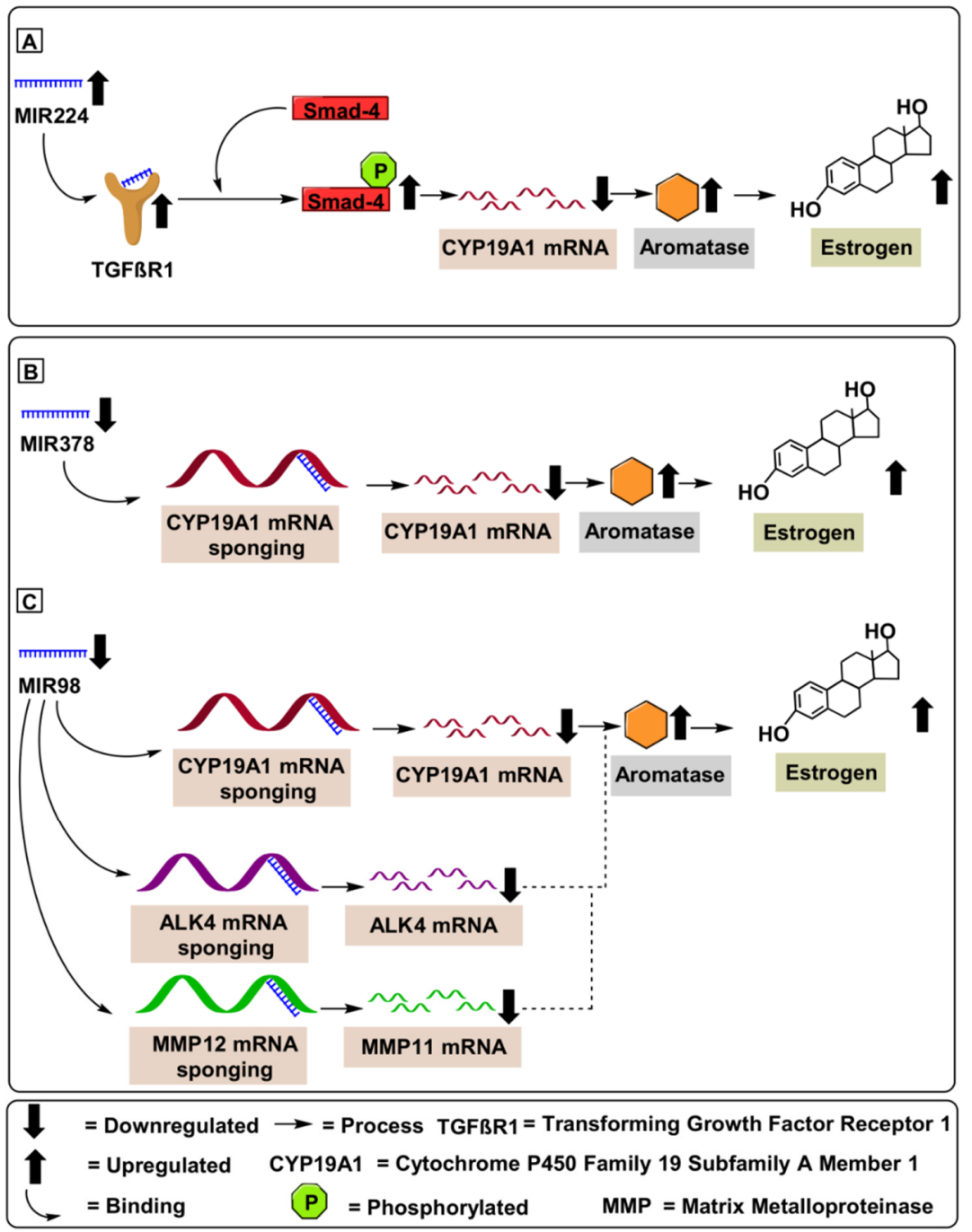

Figure 6. MicroRNAs involved in aromatase regulation in ovarian cancer. (A) Oncogenic expression of MIR224 enhances TGF- $\beta 1$ protein levels, inducing GC proliferation by targeting Smad4 protein, leading to a subsequent increase in the CYP19A1 mRNA levels. (B) Tumor suppressive role of MIR378 downregulates CYP19A1 mRNA levels in ovarian cancer patients. (C) Tumor suppressor role of MIR98 downregulates CYP19A1 mRNA levels in ovarian cancer patients furthermore, MIR98 was found to bind to the $3^{\prime}$-untranslated region of $A L K 4$ and MMP11 mRNA induced differentiation and cell proliferation. 


\section{2. $M I R 378$}

MIR378, annotated as MIR-378, MIR 378, miRNA378, hsa-mir-378, and hsa-mir-378a, is located on chromosome $5 q 32[76,77]$ and its overexpression has been correlated with inhibited cell proliferation and induced apoptosis [80]. Mechanistically, MIR378 inhibits $\mathrm{ERR} \gamma$ and GA-binding protein- $\alpha$ at the mRNA level. This suppression upregulates a critical tumor suppressive gene, PGC-1 $\beta$, which controls oxidative metabolism. Xu et al. (2011) demonstrated that decreased levels of MIR378 in porcine ovaries correlated with increased aromatase and estrogen levels. Mechanistically, MIR378 suppressed aromatase (3-fold downregulation) by targeting specific sites within the aromatase $3^{\prime}$-UTR (Table 2) [76]. A similar study performed by Pan et al. (2015) demonstrated that upregulation of MIR378 in cumulus cells of porcine ovaries resulted in decreased expression of prostaglandinendoperoxide 193 synthase 2 (PTGS2) and hyaluronan synthase 2 (HAS2) transcripts, both of which are associated with anti-angiogenesis. Furthermore, overexpressed MIR378 was found to downregulate aromatase (2.75-fold downregulation) by targeting its $3^{\prime}$-UTR [81] Table 2. Therefore, MIR378 might have potential as a therapeutic target against ovarian cancer; not only acting as an AI but also by targeting pathways associated with the suppression of tumor progression and proliferation (Figure 6).

\section{3. $M I R 98$}

MIR98 are short (20-24 nucleotide) noncoding RNAs located on chromosome $\mathrm{X}$ at Xp11.22. MIR98 is a well-documented tumor suppressor, having demonstrated the ability to inhibit cell survival, cell proliferation, tumor growth, and invasion by targeting activin receptor type-1B (ALK4) and MMP11. Mechanistically, the tumor suppressor potential of MIR98 was validated using the luciferase reporter assay, where MIR98 was found to bind to the 3'-untranslated region of $A L K 4$ and MMP11 mRNA. MMP11 accelerated the degradation of serine protease inhibitor $\alpha 1$-antitrypsin and insulin-like growth factor binding protein-1 (IGFBP-1), induced differentiation of a desmoplastic reaction surrounding the cancer stroma through cleavage of collagen $\mathrm{VI}$ and stimulated tumor progression and metastasis [78]. Similarly, ALK4 (activin receptor type-1B) activated cellular proliferation by targeting the Smad4 protein [82]. Panda et al. (2012) demonstrated the tumor-suppressive potential of MIR98 via targeting of CYP19A1 mRNA, which demonstrated reduced estrogen levels in 52 patients compared to 15 healthy individuals. Furthermore, MIR98 reduced the expression of CYP19A1 mRNA (3.5-fold downregulation). Panda et al. (2012) validated the CYP19A1 regulatory potential of MIR98 deploying in vitro (Ishikawa cells) and in vivo (52 patients and 15 healthy control samples) experimentation (Table 2). Additionally, Panda et al. (2012) correlated the inhibitory potential of MIR98 with clinicopathological features, including age, tumor grade, tumor size, and staging. Furthermore, the sponging of the CYP19A1 mRNA by MIR98 contributed to estrogen depletion and decreased tumor cell proliferation, migration, invasion, and angiogenesis, suggesting application of MIR98 as a therapeutic and diagnostic molecule in clinical settings [79].

\section{Mechanisms of Various Delivery Methods for Therapeutic miRNAs and Future Direction for Efficacious Use in the Clinical Setting}

Over the past few decades, our approach toward cancer therapeutics has transformed and continues to transition, from focusing on treating invasive cancers towards placing a greater emphasis on early detection and prevention. Additionally, advances in targeted therapies have been made to reduce detrimental side effects in patients [83,84]. For example, targeted inhibitors of aromatase have been developed to regulate estrogen synthesis in cancer cells [85]. Inhibition of such rate-limiting biomolecules may be a key to long-term treatment of a large subset of the population, while also having limited adverse side effects. However, treatment with conventional AIs, such as letrozole, anastrozole, and exemestane, often results in detrimental side effects such as osteoporosis, carpal tunnel syndrome, changes in appetite, constipation, diarrhoea, and vaginal bleeding. Thus, the developments of novel AIs with reduced side effects are needed. In this regard, ncRNA- 
based approaches to target aromatase may significantly improve conventional inhibitors, as outlined in Figures 3-6.

Within our comprehensive search of the literature, we discussed one dysregulated lncRNA and six miRNAs that have been associated with breast cancer. Similarly, we examined three dysregulated miRNAs related to ovarian cancer. Let-7f miRNA has been reported as the most potent inhibitor of aromatase, leading to a significant decrease in aromatase levels in MCF-7 and SK-BR-3 breast cancer cell lines. Additionally, these results were validated using three breast tissue samples, suggesting that let-7f may provide a novel target to substitute for conventionally-used AIs in the treatment of estrogen-sensitive breast cancers. Further studies are warranted to validate the therapeutic potential of let-7f as a substitute to conventional AI therapy [29]. Likewise, the evaluation of several ncRNAs associated with ovarian cancer demonstrated that MiR98 miRNA might be the most promising inhibitor of aromatase, as targeting this lncRNA for depletion led to a significant decrease (3.5-fold downregulation) in aromatase levels in the endometrial tumor cell line (Ishikawa cells). Of clinical relevance, similar results were found in 52 patient samples, when compared to 15 healthy control samples [79]. Thus, it might be possible to use ncRNAs as potential biomarkers and to include them in biomarker panels for diagnostic and prognostic applications in cancer patients. Furthermore, critical shortcomings associated with ncRNA delivery, immunogenicity, and suppression of oncogenic ncRNA have been well studied, and their inferences have been discussed in the subsequent section.

\subsection{Approaches for Systemic Delivery of Therapeutic ncRNAs}

ncRNA, such as microRNAs and long noncoding RNAs, are critical regulatory molecules dysregulated in cancer in tissue and stage-specific manner. Cellular penetration of ncRNA requires improved stabilization against degradation, requiring the employment of optimized chemical structures. Being structurally identical to siRNAs, similar pharmaceutical formulations encompassing lipid-based delivery vehicles, polymeric nanoparticles, and viral systems can be utilized to increase stability and enhance the pharmacokinetic potential of the associated oligonucleotides [86-88].

Furthermore, Sharma et al. (2017) exhibited enhanced efficacy of anti-miR-191, which was achieved using MCF-7 and ZR-75-1 human breast cancer epithelial cell lines. Conjugated liposomes with anti-miR-191 reported enhanced apoptosis and suppressed metastasis [89]. Despite the ease of manufacturing and protection against nucleotide degradation, the liposomal delivery mechanism is plagued with hurdles, including scalability, reliability, chemical instability, and denaturation [90].

Similarly, structural analogs, called exosomes, can also be used for the transfer of miRNA amongst cells in vivo. Exosomes are composed of the phospholipid bilayer, and the biogenesis of exosomes ensures increased biocompatibility with minimal toxicity. Recently, Gai et al. (2020) illustrated lncRNA exosomal encapsulation of metallothionein 1D pseudogene lncRNA (MTDP-lncRNA) in H1299 non-small cell lung cancer cells, which generated a favourable therapeutic effect in tumor cells via regulation of the miR-365a-3p/NRF2 axis [91]. Unfortunately, exosome manufacturing faces complications within pharmaceutical development, production, high immunogenicity, and potential biological impurities.

Furthermore, to overcome the problems associated with the aforementioned conventionally used processes, several polymers, such as polyethyleneimine (PEI), polyurethanepolyethylene imine copolymer (PU-PEI), poly lactic-co-glycolic acid (PLGA), and silicabased polymers are used as possible mechanisms for oligonucleotide delivery [92]. Comparative to the liposomal delivery mechanism, polymer-based delivery mechanisms have advantages, such as controlled delivery via regulation of the degree of cross-linking of the lattice [93]. Peng et al. (2017) demonstrated the efficient transfection of miR-200c mimics in U2OS human osteosarcoma cell lines using AMD3465 (P-SS-AMD) polymer conjugates, which were synthesized using HPMA (N-(2Hydroxypropyl) methacrylamide) and methacrylamide monomer conjugated with AMD3465, via a self-immolative disulfide linker. Transfection with miR-200c mimics demonstrated improved penetration, reduced 
degradation, and inhibition of metastasis in U2OS human osteosarcoma cell lines [94,95]. Unfortunately, polymeric systems suffer severe toxicity and unpredictability due to unwanted interactions with encapsulated oligonucleotides and biological proteins [96].

Additionally, bacteriophages have also been recently employed to develop virus-like particles, which have been used to transfer oligonucleotides and drug molecules. This has been performed with varied success. Wang et al. (2016) demonstrated the inhibitory potential of the MS2 bacteriophage virus-like particle (VLP)-based microRNA delivery system, cross-linked with the HIV TAT peptide in conjugation with miR-122, used to inhibit metastasis and tumor progression in Hep3B, HepG2, and Huh7 hepatocellular carcinoma (HCC) cell lines and Hep3B-related animal models. Unfortunately, similar to exosomes, concerns regarding high immunogenicity limit their applicability from a clinical perspective.

Depending upon the size and nature of the ncRNA discussed in the study, any of the technologies, as mentioned earlier, may be employed for the effective transfer of potential therapeutic molecules in vivo. Unfortunately, detailed reviews are warranted to prove clinical applicability.

\subsection{Suppression of Oncogenic ncRNAs}

Due to the universal availability of lncRNAs in body fluids, lncRNAs are promising therapeutic targets for cancer therapy. Their complex dynamic structure, coupled with their specific expression, provides a possible target for biomarker-driven, personalized medicine for cancer treatment. During our analysis, distinguishing lncRNA regulatory elements and upregulated patterns were observed, highlighting the need for technologies that perform functional analysis and target epigenetic modifications. Antisense oligonucleotide (ASO) is one such technology composed of a native or chemically modified (phosphorothioated) single-stranded antisense oligonucleotide, 6mer long at the central part and with RNA nucleotide at the flanking regions. Gong et al. (2018) demonstrated the inhibitory potential of MALAT1-specific ASO and nucleus-targeting TAT peptide co-functionalized Au nanoparticles (ASO-Au-TAT NPs). ASO-Au-TAT NPs enclosed MALAT1, which enhanced nuclear internalization and exhibited excellent biocompatibility in A549 lung cancer. Furthermore, reduced MALAT1 expression led to reduced metastatic tumor nodule formation in vivo [94].

Similarly, structural analogs, called locked nucleic acid GapmeRs (LNA GapmeRs), are 16 nucleotides long and contain chemically modified LNA (locked nucleic acid) in flanking arms, whereas the gap section lacks LNAs. Salehi et al. (2019) exhibited the transfection of PVT1 antisense LNA GapmeRs, which decreased the viability of AEL (acute erythroid leukaemia) cells. Additionally, PVT1 antisense LNA GapmeRs-transfected cells induced apoptosis and necrosis via downregulation of C-MYC protein [97]. Additionally, an antagonist to NATs (natural antisense transcripts) is an alternative to conventional lncRNA blockers, involving nucleotide fragments coded from the opposite strand of the host gene loci. Jadaliha et al. (2018) demonstrated positive regulation of expression and activity of the NAT-conjugated PDCD4-AS1 in the MCF10A triple-negative breast cancer mammary epithelial cells line. Furthermore, NAT-conjugated PDCD4-AS1-conjugated lncRNA was associated with the regulation of post-transcriptional gene expression involving suppression of essential oncogenic and tumor suppressor genes [98].

Mixmer molecule is another such regulatory molecule composed of chemically modified nucleotides, such as LNAs, associated with a variety of monomers. Mixmer molecules are composed of unusual sequential nucleotides, making them immune to RNase H1 degradation. These atypical nucleotides sterically inhibit the linkages amongst lncRNA and their downstream targets, preventing epigenetic remodeling, altering gene expression, and directing alternative splicing [99]. Ivanova et al. (2007) demonstrated the applicative potential of 2'-O-methyl (OMe) oligonucleotide mixmers conjugated with locked nucleic acid (LNA) residues, as they worked as a powerful steric block in inhibiting Tat-dependent transactivation in a HeLa cell reporter system inhibiting $\beta$-galactosidase. Furthermore, the 
aforementioned steric blocking inhibited the replicative potential of the human immunodeficiency virus (HIV) [100].

Complementing the strategies mentioned earlier, small interfering RNAs (siRNAs) are one of the most widely acknowledged knockdown strategies, composed of double-stranded RNA which unwind into single-stranded RNA and subsequently initiate RNA-induced silencing. Prensner et al. (2014) demonstrated siRNA-based knockdown of the second chromosome on locus-associated with prostate-1 (SChLAP1), resulting in reduced cell invasion and metastasis. LncRNA SChLAP1 caused aggressive prostate cancer by preventing the tumor-suppressive activity of the SWItch/Sucrose non-fermentable (SWI/SNF) complex [101].

Furthermore, several other techniques, including deoxyribozymes and ribozymes, zinc finger nuclease (ZNF), transcription activator-like effector nuclease (TALEN), cluster regularly interspaced short palindromic repeats, nanobodies, aptamers, RNA decoys, and more, can be used as potentially regulatory technologies. Unfortunately, a detailed analysis of all listed techniques is beyond the scope of this manuscript, and will require additional inputs. Additionally, the applicability of the strategies mentioned above depends on the nature of the target molecule, just as how siRNA is not as effective of an immunogen as ASOs are. Similarly, siRNA demonstrates a high binding affinity in targeting ncRNA localized in the cytoplasm. Contrary to the above, ASOs are preferred over siRNA when targeting ncRNA localized in the nucleus. Therefore, localization, structural properties, and nature of the target molecule need to be taken into consideration while deciding a suitable gene-silencing technology for an effective cessation of oncogenic ncRNA.

The advent of powerful detection technologies, such as high-throughput sequencing, has made the deployment of novel miRNAs/lncRNA in the clinical settings quite possible. Despite these advances, there is a considerable knowledge gap in this field; for example, several of the ncRNAs discussed were validated using either human cell lines in vitro or animal models. Therefore, there is an urgent need to verify the results in multiple in vivo human studies.

\section{Conclusions}

Based on our search, we were able to demonstrate a clear correlation amongst aberrant miRNA and lncRNA expression in association with aromatase-dependent breast and ovarian cancers. Furthermore, we compiled evidence that demonstrates a direct correlation amongst several miRNAs and the CYP19A1 gene (aromatase encoding gene). Additionally, we validated the critical role of several miRNAs in overcoming aromatase inhibitor resistance in ER-positive breast and ovarian cancer. Unfortunately, there are still gaps in understanding of the underlying mechanisms associated with aromatase inhibitor resistance in ER-positive breast and ovarian cancer. Therefore, more research is required for future developments in this area.

Author Contributions: T.S.B., and A.J. conceived the idea. T.S.B., M.J., H.P. and A.J. wrote the manuscript. U.S. prepared the figures. S.B., I.S., and S.S. constructed the tables. U.S. formatted the references as per the journal style. E.N.S. A.B. suggested improvement for scientific quality, organization, and style, performed the final editing, and administered this project. All authors have read and agreed to the published version of the manuscript.

Funding: This work was supported by the Department of Science and Technology of India through the Indo-Russia grant (INT/RUS/RFBR/P-311) to A.J. A.J. is also thankful to Indian Council of Medical Research for providing grants (5/13/81/2013-NCD-III). U.S. is supported by a Department of Science and Technology-Innovation in Science Pursuit for Inspired Research fellowship grant (IF180680).

Data Availability Statement: Not applicable.

Conflicts of Interest: The authors declare no conflict of interest. The funders had no role in the design of the study; in the collection, analyses, or interpretation of data; in the writing of the manuscript, or in the decision to publish the results. 


\section{References}

1. Sung, H.; Ferlay, J.; Siegel, R.L.; Laversanne, M.; Soerjomataram, I.; Jemal, A.; Bray, F. Global cancer statistics 2020: GLOBOCAN estimates of incidence and mortality worldwide for 36 cancers in 185 countries. CA Cancer J. Clin. 2021, in press. [CrossRef] [PubMed]

2. Norman, G.; Rice, S.; Spackman, E.; Stirk, L.; Danso-Appiah, A.; Suh, D.; Palmer, S.; Eastwood, A. Trastuzumab for the treatment of HER2-positive metastatic adenocarcinoma of the stomach or gastro-oesophageal junction. Health Technol. Assess 2011, 15 (Suppl. S1), 33-42. [CrossRef] [PubMed]

3. Bang, Y.J.; Van Cutsem, E.; Feyereislova, A.; Chung, H.C.; Shen, L.; Sawaki, A.; Lordick, F.; Ohtsu, A.; Omuro, Y.; Satoh, T.; et al. Trastuzumab in combination with chemotherapy versus chemotherapy alone for treatment of HER2-positive advanced gastric or gastro-oesophageal junction cancer (ToGA): A phase 3, open-label, randomised controlled trial. Lancet 2010, 376, 687-697. [CrossRef]

4. Menon, U.; Karpinskyj, C.; Gentry-Maharaj, A. Ovarian Cancer Prevention and Screening. Obstet. Gynecol. 2018, 131, 909-927. [CrossRef] [PubMed]

5. Najim, O.; Seghers, S.; Sergoynne, L.; Van Gaver, H.; Papadimitriou, K.; Wouters, K.; Trinh, X.B.; Huizing, M.T.; Tjalma, W. The association between type of endocrine therapy and development of estrogen receptor- 1 mutation(s) in patients with hormonesensitive advanced breast cancer: A systematic review and meta-analysis of randomized and non-randomized trials. Biochim. Biophys. Acta Rev. Cancer 2019, 1872, 188315. [CrossRef]

6. Ribas, R.; Pancholi, S.; Rani, A.; Schuster, E.; Guest, S.K.; Nikitorowicz-Buniak, J.; Simigdala, N.; Thornhill, A.; Avogadri-Connors, F.; Cutler, R.E., Jr.; et al. Targeting tumour re-wiring by triple blockade of mTORC1, epidermal growth factor, and oestrogen receptor signalling pathways in endocrine-resistant breast cancer. Breast Cancer Res. 2018, 20, 44. [CrossRef]

7. Osawa, Y.; Higashiyama, T.; Fronckowiak, M.; Yoshida, N.; Yarborough, C. Aromatase. J. Steroid Biochem. 1987, $27,781-789$.

8. Simpson, E.R.; Clyne, C.; Rubin, G.; Boon, W.C.; Robertson, K.; Britt, K.; Speed, C.; Jones, M. Aromatase-A brief overview. Annu . Rev. Physiol. 2002, 64, 93-127. [CrossRef] [PubMed]

9. Zhao, H.; Zhou, L.; Shangguan, A.J.; Bulun, S.E. Aromatase expression and regulation in breast and endometrial cancer. J. Mol. Endocrinol. 2016, 57, R19-R33. [CrossRef]

10. Bulun, S.E.; Chen, D.; Lu, M.; Zhao, H.; Cheng, Y.; Demura, M.; Yilmaz, B.; Martin, R.; Utsunomiya, H.; Thung, S.; et al. Aromatase excess in cancers of breast, endometrium and ovary. J. Steroid Biochem. Mol. Biol. 2007, 106, 81-96. [CrossRef]

11. Berry, J. Are all aromatase inhibitors the same? A review of controlled clinical trials in breast cancer. Clin. Ther. 2005, 27, 1671-1684. [CrossRef] [PubMed]

12. Khandelwal, A.; Bacolla, A.; Vasquez, K.M.; Jain, A. Long non-coding RNA: A new paradigm for lung cancer. Mol. Carcinog. 2015, 54, 1235-1251. [CrossRef]

13. Tamang, S.; Acharya, V.; Roy, D.; Sharma, R.; Aryaa, A.; Sharma, U.; Khandelwal, A.; Prakash, H.; Vasquez, K.M.; Jain, A. SNHG12: An LncRNA as a Potential Therapeutic Target and Biomarker for Human Cancer. Front. Oncol. 2019, 9, 901. [CrossRef]

14. Barwal, T.S.; Sharma, U.; Vasquez, K.M.; Prakash, H.; Jain, A. A panel of circulating long non-coding RNAs as liquid biopsy biomarkers for breast and cervical cancers. Biochimie 2020, 176, 62-70. [CrossRef]

15. Pandey, A.D.; Goswami, S.; Shukla, S.; Das, S.; Ghosal, S.; Pal, M.; Bandyopadhyay, B.; Ramachandran, V.; Basu, N.; Sood, V.; et al. Correlation of altered expression of a long non-coding RNA, NEAT1, in peripheral blood mononuclear cells with dengue disease progression. J. Infect. 2017, 75, 541-554. [CrossRef] [PubMed]

16. Yip, C.H.; Rhodes, A. Estrogen and progesterone receptors in breast cancer. Future Oncol. 2014, 10, 2293-2301. [CrossRef]

17. Bray, F.; Ferlay, J.; Soerjomataram, I.; Siegel, R.L.; Torre, L.A.; Jemal, A. Global cancer statistics 2018: GLOBOCAN estimates of incidence and mortality worldwide for 36 cancers in 185 countries. CA Cancer J. Clin. 2018, 68, 394-424. [CrossRef]

18. Siegel, R.L.; Miller, K.D.; Jemal, A. Cancer statistics, 2020. CA Cancer J. Clin. 2020, 70, 7-30. [CrossRef] [PubMed]

19. Mungenast, F.; Thalhammer, T. Estrogen biosynthesis and action in ovarian cancer. Front. Endocrinol. 2014, 5, 192. [CrossRef] [PubMed]

20. Cairns, J.; Ingle, J.N.; Kalari, K.R.; Shepherd, L.E.; Kubo, M.; Goetz, M.P.; Weinshilboum, R.M.; Wang, L. The lncRNA MIR2052HG regulates ERalpha levels and aromatase inhibitor resistance through LMTK3 by recruiting EGR1. Breast Cancer Res. 2019, 21, 47. [CrossRef] [PubMed]

21. Ingle, J.N.; Xie, F.; Ellis, M.J.; Goss, P.E.; Shepherd, L.E.; Chapman, J.W.; Chen, B.E.; Kubo, M.; Furukawa, Y.; Momozawa, Y.; et al. Genetic Polymorphisms in the Long Noncoding RNA MIR2052HG Offer a Pharmacogenomic Basis for the Response of Breast Cancer Patients to Aromatase Inhibitor Therapy. Cancer Res. 2016, 76, 7012-7023. [CrossRef]

22. Ghimenti, C.; Mello-Grand, M.; Grosso, E.; Scatolini, M.; Regolo, L.; Zambelli, A.; Chiorino, G. Regulation of aromatase expression in breast cancer treated with anastrozole neoadjuvant therapy. Exp. Ther. Med. 2013, 5, 902-906. [CrossRef] [PubMed]

23. Katchy, A.; Williams, C. Profiling of estrogen-regulated microRNAs in breast cancer cells. J. Vis. Exp. 2014, 84, e51285. [CrossRef] [PubMed]

24. Spear, R.; Boytard, L.; Blervaque, R.; Chwastyniak, M.; Hot, D.; Vanhoutte, J.; Lamblin, N.; Amouyel, P.; Pinet, F. Let-7f: A New Potential Circulating Biomarker Identified by miRNA Profiling of Cells Isolated from Human Abdominal Aortic Aneurysm. Int. J. Mol. Sci. 2019, 20, 5499. [CrossRef] [PubMed]

25. Roush, S.; Slack, F.J. The let-7 family of microRNAs. Trends Cell Biol. 2008, 18, 505-516. [CrossRef] [PubMed] 
26. Selvamani, A.; Sathyan, P.; Miranda, R.C.; Sohrabji, F. An antagomir to microRNA Let7f promotes neuroprotection in an ischemic stroke model. PLoS ONE 2012, 7, e32662. [CrossRef] [PubMed]

27. Bussing, I.; Slack, F.J.; Grosshans, H. let-7 microRNAs in development, stem cells and cancer. Trends Mol. Med. 2008, 14, 400-409. [CrossRef] [PubMed]

28. Liu, D.; Deng, Q.; Sun, L.; Wang, T.; Yang, Z.; Chen, H.; Guo, L.; Liu, Y.; Ma, Y.; Guo, N.; et al. A Her2-let-7-beta2-AR circuit affects prognosis in patients with Her2-positive breast cancer. BMC Cancer 2015, 15, 832. [CrossRef]

29. Shibahara, Y.; Miki, Y.; Onodera, Y.; Hata, S.; Chan, M.S.; Yiu, C.C.; Loo, T.Y.; Nakamura, Y.; Akahira, J.; Ishida, T.; et al. Aromatase inhibitor treatment of breast cancer cells increases the expression of let-7f, a microRNA targeting CYP19A1. J. Pathol. 2012, 227, 357-366. [CrossRef] [PubMed]

30. Tao, W.Y.; Liang, X.S.; Liu, Y.; Wang, C.Y.; Pang, D. Decrease of let-7f in low-dose metronomic Paclitaxel chemotherapy contributed to upregulation of thrombospondin-1 in breast cancer. Int. J. Biol. Sci. 2015, 11, 48-58. [CrossRef]

31. Shao, X.; Huang, P.; Shi, L.; Lei, L.; Cao, W.; Chen, Z.; Wang, X.; Zheng, Y. MicroRNA and LncRNA Expression Profiles in Human Estrogen Receptor Positive Breast Cancer. Clin. Lab. 2019, 65, 180340. [CrossRef] [PubMed]

32. Li, Y.; Song, Y.; Wang, Z.; Zhang, Z.; Lu, M.; Wang, Y. Long Non-coding RNA LINC01787 Drives Breast Cancer Progression via Disrupting miR-125b Generation. Front. Oncol. 2019, 9, 1140. [CrossRef]

33. Banno, K.; Yanokura, M.; Iida, M.; Adachi, M.; Nakamura, K.; Nogami, Y.; Umene, K.; Masuda, K.; Kisu, I.; Nomura, H.; et al. Application of microRNA in diagnosis and treatment of ovarian cancer. BioMed Res. Int. 2014, 2014, 232817. [CrossRef] [PubMed]

34. Vilquin, P.; Donini, C.F.; Villedieu, M.; Grisard, E.; Corbo, L.; Bachelot, T.; Vendrell, J.A.; Cohen, P.A. MicroRNA-125b upregulation confers aromatase inhibitor resistance and is a novel marker of poor prognosis in breast cancer. Breast Cancer Res. 2015, 17, 13. [CrossRef] [PubMed]

35. Vilquin, P.; Villedieu, M.; Grisard, E.; Ben Larbi, S.; Ghayad, S.E.; Heudel, P.E.; Bachelot, T.; Corbo, L.; Treilleux, I.; Vendrell, J.A.; et al. Molecular characterization of anastrozole resistance in breast cancer: Pivotal role of the Akt/mTOR pathway in the emergence of de novo or acquired resistance and importance of combining the allosteric Akt inhibitor MK-2206 with an aromatase inhibitor. Int. J. Cancer 2013, 133, 1589-1602. [CrossRef] [PubMed]

36. Hannafon, B.N.; Cai, A.; Calloway, C.L.; Xu, Y.F.; Zhang, R.; Fung, K.M.; Ding, W.Q. miR-23b and miR-27b are oncogenic microRNAs in breast cancer: Evidence from a CRISPR/Cas9 deletion study. BMC Cancer 2019, 19, 642. [CrossRef] [PubMed]

37. Ding, L.; Ni, J.; Yang, F.; Huang, L.; Deng, H.; Wu, Y.; Ding, X.; Tang, J. Promising therapeutic role of miR-27b in tumor. Tumour Biol. 2017, 39, 1010428317691657. [CrossRef]

38. Zhu, J.; Zou, Z.; Nie, P.; Kou, X.; Wu, B.; Wang, S.; Song, Z.; He, J. Downregulation of microRNA-27b-3p enhances tamoxifen resistance in breast cancer by increasing NR5A2 and CREB1 expression. Cell Death Dis. 2016, 7, e2454. [CrossRef] [PubMed]

39. Zuo, J.; Yu, Y.; Zhu, M.; Jing, W.; Yu, M.; Chai, H.; Liang, C.; Tu, J. Inhibition of miR-155, a therapeutic target for breast cancer, prevented in cancer stem cell formation. Cancer Biomark. 2018, 21, 383-392. [CrossRef]

40. Bacci, M.; Giannoni, E.; Fearns, A.; Ribas, R.; Gao, Q.; Taddei, M.L.; Pintus, G.; Dowsett, M.; Isacke, C.M.; Martin, L.A.; et al miR-155 Drives Metabolic Reprogramming of ER+ Breast Cancer Cells Following Long-Term Estrogen Deprivation and Predicts Clinical Response to Aromatase Inhibitors. Cancer Res. 2016, 76, 1615-1626. [CrossRef] [PubMed]

41. Volinia, S.; Calin, G.A.; Liu, C.G.; Ambs, S.; Cimmino, A.; Petrocca, F.; Visone, R.; Iorio, M.; Roldo, C.; Ferracin, M.; et al. A microRNA expression signature of human solid tumors defines cancer gene targets. Proc. Natl. Acad. Sci. USA 2006, 103, 2257-2261. [CrossRef]

42. Shang, S.; Hua, F.; Hu, Z.W. The regulation of beta-catenin activity and function in cancer: Therapeutic opportunities. Oncotarget 2017, 8, 33972-33989. [CrossRef]

43. Li, M.; Fu, W.; Wo, L.; Shu, X.; Liu, F.; Li, C. miR-128 and its target genes in tumorigenesis and metastasis. Exp. Cell Res. 2013, 319, 3059-3064. [CrossRef]

44. Masri, S.; Liu, Z.; Phung, S.; Wang, E.; Yuan, Y.C.; Chen, S. The role of microRNA-128a in regulating TGFbeta signaling in letrozole-resistant breast cancer cells. Breast Cancer Res. Treat. 2010, 124, 89-99. [CrossRef] [PubMed]

45. Melzer, D.; Perry, J.R.; Hernandez, D.; Corsi, A.M.; Stevens, K.; Rafferty, I.; Lauretani, F.; Murray, A.; Gibbs, J.R.; Paolisso, G.; et al. A genome-wide association study identifies protein quantitative trait loci (pQTLs). PLoS Genet. 2008, 4, e1000072. [CrossRef] [PubMed]

46. Ota, T.; Suzuki, Y.; Nishikawa, T.; Otsuki, T.; Sugiyama, T.; Irie, R.; Wakamatsu, A.; Hayashi, K.; Sato, H.; Nagai, K.; et al. Complete sequencing and characterization of 21,243 full-length human cDNAs. Nat. Genet. 2004, 36, 40-45. [CrossRef] [PubMed]

47. Sahibzada, M.U.K.; Sadiq, A.; Khan, S.; Faidah, H.S.; Naseemullah; Khurram, M.; Amin, M.U.; Haseeb, A. Fabrication, characterization and in vitro evaluation of silibinin nanoparticles: An attempt to enhance its oral bioavailability. Drug Des. Dev. Ther. 2017, 11, 1453-1464. [CrossRef]

48. Faraoni, I.; Antonetti, F.R.; Cardone, J.; Bonmassar, E. miR-155 gene: A typical multifunctional microRNA. Biochim. Biophys. Acta 2009, 1792, 497-505. [CrossRef] [PubMed]

49. Yan, L.X.; Huang, X.F.; Shao, Q.; Huang, M.Y.; Deng, L.; Wu, Q.L.; Zeng, Y.X.; Shao, J.Y. MicroRNA miR-21 overexpression in human breast cancer is associated with advanced clinical stage, lymph node metastasis and patient poor prognosis. RNA 2008, 14, 2348-2360. [CrossRef] [PubMed]

50. Iorio, M.V.; Ferracin, M.; Liu, C.G.; Veronese, A.; Spizzo, R.; Sabbioni, S.; Magri, E.; Pedriali, M.; Fabbri, M.; Campiglio, M.; et al. MicroRNA gene expression deregulation in human breast cancer. Cancer Res. 2005, 65, 7065-7070. [CrossRef] 
51. Wang, X.; Tang, S.; Le, S.Y.; Lu, R.; Rader, J.S.; Meyers, C.; Zheng, Z.M. Aberrant expression of oncogenic and tumor-suppressive microRNAs in cervical cancer is required for cancer cell growth. PLoS ONE 2008, 3, e2557. [CrossRef] [PubMed]

52. Lee, E.J.; Gusev, Y.; Jiang, J.; Nuovo, G.J.; Lerner, M.R.; Frankel, W.L.; Morgan, D.L.; Postier, R.G.; Brackett, D.J.; Schmittgen, T.D Expression profiling identifies microRNA signature in pancreatic cancer. Int. J. Cancer 2007, 120, 1046-1054. [CrossRef] [PubMed]

53. Yanaihara, N.; Caplen, N.; Bowman, E.; Seike, M.; Kumamoto, K.; Yi, M.; Stephens, R.M.; Okamoto, A.; Yokota, J.; Tanaka, T.; et al. Unique microRNA molecular profiles in lung cancer diagnosis and prognosis. Cancer Cell 2006, 9, 189-198. [CrossRef] [PubMed]

54. Sun, X.; Dai, G.; Yu, L.; Hu, Q.; Chen, J.; Guo, W. miR-143-3p inhibits the proliferation, migration and invasion in osteosarcoma by targeting FOSL2. Sci. Rep. 2018, 8, 606. [CrossRef] [PubMed]

55. Galardi, S.; Mercatelli, N.; Giorda, E.; Massalini, S.; Frajese, G.V.; Ciafre, S.A.; Farace, M.G. miR-221 and miR-222 expression affects the proliferation potential of human prostate carcinoma cell lines by targeting p27Kip1. J. Biol. Chem. 2007, 282, 23716-23724. [CrossRef]

56. Garofalo, M.; Quintavalle, C.; Romano, G.; Croce, C.M.; Condorelli, G. miR221/222 in cancer: Their role in tumor progression and response to therapy. Curr. Mol. Med. 2012, 12, 27-33. [CrossRef]

57. Rao, X.; Di Leva, G.; Li, M.; Fang, F.; Devlin, C.; Hartman-Frey, C.; Burow, M.E.; Ivan, M.; Croce, C.M.; Nephew, K.P. MicroRNA221/222 confers breast cancer fulvestrant resistance by regulating multiple signaling pathways. Oncogene 2011, 30, $1082-1097$. [CrossRef]

58. Morin, P.J. $\beta$-catenin signaling and cancer. Bioessays 1999, 21, 1021-1030. [CrossRef]

59. Qian, P.; Banerjee, A.; Wu, Z.S.; Zhang, X.; Wang, H.; Pandey, V.; Zhang, W.J.; Lv, X.F.; Tan, S.; Lobie, P.E.; et al. Loss of SNAIL regulated miR-128-2 on chromosome 3p22.3 targets multiple stem cell factors to promote transformation of mammary epithelial cells. Cancer Res. 2012, 72, 6036-6050. [CrossRef] [PubMed]

60. Liu, S.; Chen, S.; Zeng, J. TGFbeta signaling: A complex role in tumorigenesis (Review). Mol. Med. Rep. 2018, 17, 699-704. [PubMed]

61. Saluja, R.; Kumar, A.; Jain, M.; Goel, S.K.; Jain, A. Role of Sphingosine-1-Phosphate in Mast Cell Functions and Asthma and Its Regulation by Non-Coding RNA. Front. Immunol. 2017, 8, 587. [CrossRef] [PubMed]

62. Sharma, U.; Barwal, T.S.; Acharya, V.; Tamang, S.; Vasquez, K.M.; Jain, A. Cancer Susceptibility Candidate 9 (CASC9): A Novel Targetable Long Noncoding RNA in Cancer Treatment. Transl. Oncol. 2020, 13, 100774. [CrossRef] [PubMed]

63. Sharma, U.; Barwal, T.S.; Malhotra, A.; Pant, N.; Vivek; Dey, D.; Gautam, A.; Tuli, H.S.; Vasquez, K.M.; Jain, A. Long non-coding RNA TINCR as potential biomarker and therapeutic target for cancer. Life Sci. 2020, 257, 118035. [CrossRef] [PubMed]

64. Tian, T.; Wang, M.; Lin, S.; Guo, Y.; Dai, Z.; Liu, K.; Yang, P.; Dai, C.; Zhu, Y.; Zheng, Y.; et al. The Impact of lncRNA Dysregulation on Clinicopathology and Survival of Breast Cancer: A Systematic Review and Meta-analysis. Mol. Ther. Nucleic Acids 2018, 12, 359-369. [CrossRef] [PubMed]

65. Wentzensen, N.; Poole, E.M.; Trabert, B.; White, E.; Arslan, A.A.; Patel, A.V.; Setiawan, V.W.; Visvanathan, K.; Weiderpass, E.; Adami, H.O.; et al. Ovarian Cancer Risk Factors by Histologic Subtype: An Analysis from the Ovarian Cancer Cohort Consortium. J. Clin. Oncol. 2016, 34, 2888-2898. [CrossRef] [PubMed]

66. Jayson, G.C.; Kohn, E.C.; Kitchener, H.C.; Ledermann, J.A. Ovarian cancer. Lancet 2014, 384, 1376-1388. [CrossRef]

67. Tew, W.P. Ovarian cancer in the older woman. J. Geriatr. Oncol. 2016, 7, 354-361. [CrossRef] [PubMed]

68. Reid, B.M.; Permuth, J.B.; Sellers, T.A. Epidemiology of ovarian cancer: A review. Cancer Biol. Med. 2017, 14, 9-32. [PubMed]

69. Modugno, F.; Laskey, R.; Smith, A.L.; Andersen, C.L.; Haluska, P.; Oesterreich, S. Hormone response in ovarian cancer: Time to reconsider as a clinical target? Endocr. Relat. Cancer 2012, 19, R255-R279. [CrossRef]

70. Langdon, S.P.; Herrington, C.S.; Hollis, R.L.; Gourley, C. Estrogen Signaling and Its Potential as a Target for Therapy in Ovarian Cancer. Cancers 2020, 12, 1647. [CrossRef]

71. Chan, H.J.; Petrossian, K.; Chen, S. Structural and functional characterization of aromatase, estrogen receptor, and their genes in endocrine-responsive and -resistant breast cancer cells. J. Steroid Biochem. Mol. Biol. 2016, 161, 73-83. [CrossRef]

72. Hurteau, J.A.; Brady, M.F.; Darcy, K.M.; McGuire, W.P.; Edmonds, P.; Pearl, M.L.; Ivanov, I.; Tewari, K.S.; Mannel, R.S.; Zanotti, K.; et al. Randomized phase III trial of tamoxifen versus thalidomide in women with biochemical-recurrent-only epithelial ovarian, fallopian tube or primary peritoneal carcinoma after a complete response to first-line platinum/taxane chemotherapy with an evaluation of serum vascular endothelial growth factor (VEGF): A Gynecologic Oncology Group Study. Gynecol. Oncol. 2010, 119, 444-450. [PubMed]

73. Musahl, A.S.; Huang, X.; Rusakiewicz, S.; Ntini, E.; Marsico, A.; Kroemer, G.; Kepp, O.; Orom, U.A. A long non-coding RNA links calreticulin-mediated immunogenic cell removal to RB1 transcription. Oncogene 2015, 34, 5046-5054. [CrossRef] [PubMed]

74. Zhao, H.; Bi, T.; Qu, Z.; Jiang, J.; Cui, S.; Wang, Y. Expression of miR-224-5p is associated with the original cisplatin resistance of ovarian papillary serous carcinoma. Oncol. Rep. 2014, 32, 1003-1012. [CrossRef] [PubMed]

75. Lite, C.; Ahmed, S.; Santosh, W.; Seetharaman, B. Prenatal exposure to bisphenol-A altered miRNA-224 and protein expression of aromatase in ovarian granulosa cells concomitant with elevated serum estradiol levels in F1 adult offspring. J. Biochem. Mol. Toxicol. 2019, 33, e22317. [CrossRef] [PubMed]

76. Xu, S.; Linher-Melville, K.; Yang, B.B.; Wu, D.; Li, J. Micro-RNA378 (miR-378) regulates ovarian estradiol production by targeting aromatase. Endocrinology 2011, 152, 3941-3951. [CrossRef]

77. Wolfram, C. The benefits of professional credentialing. J. Intraven. Nurs. 1991, 14, 362-363. 
78. Zhang, X.; Huang, S.; Guo, J.; Zhou, L.; You, L.; Zhang, T.; Zhao, Y. Insights into the distinct roles of MMP-11 in tumor biology and future therapeutics (Review). Int. J. Oncol. 2016, 48, 1783-1793. [CrossRef]

79. Panda, H.; Chuang, T.D.; Luo, X.; Chegini, N. Endometrial miR-181a and miR-98 expression is altered during transition from normal into cancerous state and target PGR, PGRMC1, CYP19A1, DDX3X, and TIMP3. J. Clin. Endocrinol. Metab. 2012, 97, E1316-E1326. [CrossRef]

80. Zeng, M.; Zhu, L.; Li, L.; Kang, C. miR-378 suppresses the proliferation, migration and invasion of colon cancer cells by inhibiting SDAD1. Cell Mol. Biol. Lett. 2017, 22, 12. [CrossRef]

81. Pan, B.; Toms, D.; Shen, W.; Li, J. MicroRNA-378 regulates oocyte maturation via the suppression of aromatase in porcine cumulus cells. Am. J. Physiol. Endocrinol. Metab. 2015, 308, E525-E534. [CrossRef] [PubMed]

82. Lebrun, J.J.; Takabe, K.; Chen, Y.; Vale, W. Roles of pathway-specific and inhibitory Smads in activin receptor signaling. Mol. Endocrinol. 1999, 13, 15-23. [CrossRef] [PubMed]

83. Pucci, C.; Martinelli, C.; Ciofani, G. Innovative approaches for cancer treatment: Current perspectives and new challenges. Ecancermedicalscience 2019, 13, 961. [CrossRef] [PubMed]

84. Masoud, V.; Pages, G. Targeted therapies in breast cancer: New challenges to fight against resistance. World J. Clin. Oncol. 2017, 8, 120-134. [CrossRef]

85. Nagini, S. Breast Cancer: Current Molecular Therapeutic Targets and New Players. Anticancer Agents Med. Chem. 2017, 17, 152-163. [CrossRef]

86. Wang, H.; Jiang, Y.; Peng, H.; Chen, Y.; Zhu, P.; Huang, Y. Recent progress in microRNA delivery for cancer therapy by non-viral synthetic vectors. Adv. Drug Deliv. Rev. 2015, 81, 142-160. [CrossRef]

87. Szebeni, J.; Muggia, F.; Gabizon, A.; Barenholz, Y. Activation of complement by therapeutic liposomes and other lipid excipientbased therapeutic products: Prediction and prevention. Adv. Drug Deliv. Rev. 2011, 63, 1020-1030. [CrossRef]

88. Szebeni, J.; Moghimi, S.M. Liposome triggering of innate immune responses: A perspective on benefits and adverse reactions. J. Liposome Res. 2009, 19, 85-90. [CrossRef]

89. Sharma, S.; Rajendran, V.; Kulshreshtha, R.; Ghosh, P.C. Enhanced efficacy of anti-miR-191 delivery through stearylamine liposome formulation for the treatment of breast cancer cells. Int. J. Pharm. 2017, 530, 387-400. [CrossRef]

90. Sercombe, L.; Veerati, T.; Moheimani, F.; Wu, S.Y.; Sood, A.K.; Hua, S. Advances and Challenges of Liposome Assisted Drug Delivery. Front. Pharmacol. 2015, 6, 286. [CrossRef] [PubMed]

91. Gai, C.; Liu, C.; Wu, X.; Yu, M.; Zheng, J.; Zhang, W.; Lv, S.; Li, W. MT1DP loaded by folate-modified liposomes sensitizes erastin-induced ferroptosis via regulating miR-365a-3p/NRF2 axis in non-small cell lung cancer cells. Cell Death Dis. 2020, 11, 751. [CrossRef]

92. Juliano, R.L. The delivery of therapeutic oligonucleotides. Nucleic Acids Res. 2016, 44, 6518-6548. [CrossRef]

93. Ma, D.; Tian, S.; Baryza, J.; Luft, J.C.; DeSimone, J.M. Reductively Responsive Hydrogel Nanoparticles with Uniform Size, Shape, and Tunable Composition for Systemic siRNA Delivery in Vivo. Mol. Pharm. 2015, 12, 3518-3526. [CrossRef]

94. Gong, N.; Teng, X.; Li, J.; Liang, X.J. Antisense Oligonucleotide-Conjugated Nanostructure-Targeting lncRNA MALAT1 Inhibits Cancer Metastasis. ACS Appl. Mater Interfaces 2019, 11, 37-42. [CrossRef]

95. Peng, Z.H.; Xie, Y.; Wang, Y.; Li, J.; Oupicky, D. Dual-Function Polymeric HPMA Prodrugs for the Delivery of miRNA. Mol. Pharm. 2017, 14, 1395-1404. [CrossRef]

96. Eckstein, F. Phosphorothioates, essential components of therapeutic oligonucleotides. Nucleic Acid Ther. 2014, 24, 374-387. [CrossRef] [PubMed]

97. Salehi, M.; Sharifi, M.; Bagheri, M. Knockdown of Long Noncoding RNA Plasmacytoma Variant Translocation 1 with Antisense Locked Nucleic Acid GapmeRs Exerts Tumor-Suppressive Functions in Human Acute Erythroleukemia Cells Through Downregulation of C-MYC Expression. Cancer Biother. Radiopharm. 2019, 34, 371-379. [CrossRef] [PubMed]

98. Jadaliha, M.; Gholamalamdari, O.; Tang, W.; Zhang, Y.; Petracovici, A.; Hao, Q.; Tariq, A.; Kim, T.G.; Holton, S.E.; Singh, D.K.; et al. A natural antisense lncRNA controls breast cancer progression by promoting tumor suppressor gene mRNA stability. PLoS Genet. 2018, 14, e1007802. [CrossRef] [PubMed]

99. Kole, R.; Krainer, A.R.; Altman, S. RNA therapeutics: Beyond RNA interference and antisense oligonucleotides. Nat. Rev. Drug Discov. 2012, 11, 125-140. [CrossRef]

100. Ivanova, G.; Reigadas, S.; Ittig, D.; Arzumanov, A.; Andreola, M.L.; Leumann, C.; Toulme, J.J.; Gait, M.J. Tricyclo-DNA containing oligonucleotides as steric block inhibitors of human immunodeficiency virus type 1 tat-dependent trans-activation and HIV-1 infectivity. Oligonucleotides 2007, 17, 54-65. [CrossRef]

101. Prensner, J.R.; Iyer, M.K.; Sahu, A.; Asangani, I.A.; Cao, Q.; Patel, L.; Vergara, I.A.; Davicioni, E.; Erho, N.; Ghadessi, M.; et al. The long noncoding RNA SChLAP1 promotes aggressive prostate cancer and antagonizes the SWI/SNF complex. Nat. Genet. 2013, 45, 1392-1398. [CrossRef] [PubMed] 